\title{
R\&D and Innovation Management in the Brazilian Electricity Sector: The Regulatory Constraint
}

\author{
Denile Cominato Boer', Sergio L.M. Salles-Filho², Adriana Bin ${ }^{3}$
}

\begin{abstract}
In 2000 it became mandatory to the Brazilian electricity companies to invest in research, development and innovation (RDI). These investments are performed by firms and regulated by the Brazilian Electricity Regulatory Agency (ANEEL). Since then companies have sought ways to cope with this obligation creating internal structures and managerial processes. This article presents the evolution of RDI management routines and organizational models based on a multiple-case study conducted between $201 \mathrm{I}$ and 2012 with seven companies that represent about $27 \%$ of the total RDI investment performed in the period of 2008 to 2013 . The research showed that firms created minimalist management and organizational structures to handle with the RDI enforcement. Companies have been much more concerned with the regulatory risk (the risk of non-accomplishment with the obligations) than to any strategic use of RDI effort since the legal framework is based on punishment rather than in stimulus.
\end{abstract}

Keywords: research and development (R\&D); innovation policy; R\&D management; electricity sector.

\footnotetext{
'Department of Science and Technology Policy, University of Campinas, POBox 6I52, Campinas, SP, Brazil. E-mail:decboer@hotmail.com. ${ }^{2}$ Department of Science and Technology Policy, University of Campinas, POBox 6152, Campinas, SP, Brazil - E-mail: sallesfi@ige.unicamp.br. ${ }^{3}$ School of Applied Sciences, University of Campinas, R. Pedro Zacarias 1300, Limeira, SP, Brazil- E-mail: adriana.bin@fca.unicamp.br.
} 


\section{Introduction}

The two last decades have shown a period of intense changes in the Brazilian electricity sector, starting by technical and economical restructuring and privatization processes in the electricity concessionaries. In this context Law n. 9991/2000 was passed obliging electricity concessionaries to invest a percentage of their Net Operating Income (NOI) in research and development (R\&D), as well as other investment obligations (Baer and McDonald, 1998; Jannuzzi, 2000).

The law has also established that part of the research resources should be directly managed by the companies by means of projects that would be part of their R\&D annual programs, regulated by the Brazilian Electricity Regulatory Agency (ANEEL), as can be seen in Campos, et. al. (2007), Jannuzzi (2005) and Cunha, et. al. (2008). Since then, these companies had sought ways to manage the R\&D resources and projects, which has led to the creation of internal management processes and routines.

This article aims to discuss the evolution of the R\&D and innovation (RDI) managerial mechanisms that took place in the Brazilian electricity companies in the period of 2008 to 2013 as a response to the regulatory requirements. The main research question is to know in which extent the companies in the sector, whether they were involved in Generation, Transmission or Distribution (GTD) systems, have taken advantage of the legal provision to create internal management and organizational structures and competences to lead their RDI activities.

For such, a study on the management and organizational models of GTD companies in the country was developed with emphasis in the period between 2008 and 2013. A total of seven companies were studied. Through documentary analyzes and questionnaires, it was possible to characterize the competences and RDI management and organizational mechanisms created to deal with the impositions of the Law. This article is structured as follows. The next section presents a review of the literature on the relations between structural changes in the electricity sector in a global perspective and its main implications to RDI investments. The third section presents the R\&D milestone for the electricity sector in Brazil and its consequences to RDI activities. The research methodology is presented in the fourth section, whilst the fifth one is dedicated to the main findings in the selected companies. The sixth section discusses the results found, and lastly, the paper conclusions are presented, showing that the companies have developed minimalist structures and competences due to the regulatory characteristics that are mainly based on obligations and punishments than on incentives.

\section{Changes in the milestone of the electricity sector and RDI trajectories: a global phenomenon}

The 1990's witnessed important changes in the organization and regulation models in the electricity sector in several countries. The withdrawal of the State and of the "natural monopoly" concept, the introduction (although partial) of more competition, the economic separation of generation, transmission and distribution activities (deverticalization) and the creation of regulatory mechanisms in agencies not totally subordinated to governments, with autonomy to analyze the performance of the sector and ensure greater technical and economic efficiency were the main features of this movement, as seen in Jamasb (2006) for developing countries and in Jamasb and Pollitt (2008) for the electricity industry as a whole.

In the Brazilian case, the extension of this movement was not as intense as the one observed in great part of the European countries, as seen in Helm and Jenkinson (1998). In Brazil, not all segments (transmission, for instance) were privatized and some of the large companies still remain state owned. Despite the changes introduced in the 1990's, the regulation model in the Brazilian electricity sector is considered very strict, not leaving much room for competition (Jannuzzi, 2005). The contracts of concession are long term (ranging between 15 to 30 years, with the possibility of renewal for the same period) and there is a price regulation component that considers the interests of consumers. Such component is known as "affordable tariffs". It is clear that the electricity sector is one of the most sensitive in terms of pricing due to its horizontality in the society, thus the affordable tariffs being an element that is always present in the electricity sector regulation policies.

Under the technological point of view, the electricity sector presents certain stability, precisely due to the scales of investment and periods of depreciation and obsolescence, in the range of decades. In fact, the great source of technological innovation in the electricity sector is within the supplying companies and global manufacturers of electric equipment, which have irrelevant presence in the Brazilian scenario in terms of local R\&D execution. The GTD segments are, according to the Pavitt's classification (Pavitt, 1984), supplier dominated, which means that innovation comes from outside companies. That does not mean the GTD companies have no internal efforts of innovation at all. These segments also present their own, internal innovating content, focused mainly on services and softwares that improve productive processes. However, it is well known that the technological trajectories of this sector are mainly determined by global suppliers of electrical equipments. Soares (1997) and Furtado (20II), in their analysis of the evolution of R\&D and innovation activities in the Brazilian electricity sector, found some similar conclusions. 
In every way, the sectorial restructuring movement, both globally and in Brazil, had consequences for the R\&D and innovation activities. Several authors have reported that this process had negative impact on the research activity in several countries.

Jamasb and Pollitt $(2008 ; 20 \mathrm{II})$ analyzed the relationship between the liberalization of the electricity sector in the world in the 1990's and the research and innovation trajectories. The authors demonstrated that there was a strong decline in R\&D investments, due in great part to the growing technological stabilization that followed the new regulation.

The same authors analyzed the English case (Jamasb and Pollitt, 20II) and pointed out that along with the decrease in R\&D investments there was, soon after the privatization of the sector, a growth in the number of patents. According to the authors, this happened due to the stripping of technologies on behalf of the electrical equipment companies in face of the commercial liberalization of the decade. In the years 2000 , the authors showed a decline in the patenting activity, due to the previous R\&D decline and also to the maturity reached by the GTD segments post-privatization.

Schimitt and Kucsera (2013) analyzing several countries in Europe, found strong evidence of a negative relationship between the process of regulatory reforms and the investments in R\&D. These authors explain this negative relationship based on the milestones of long-term concessions and low competition in the privatization processes, as well as, of course, on the withdrawal of the State as a funding entity.

Schimitt and Kucsera (2013) indicate that the period between the 1980's and the beginning of the 2000's was a period of decline in research investments, with a recovery from 2007 in a few countries, when greater competition started to happen among the companies, and the introduction of new technologies became the focus of energy policies. What the authors state is that as the new regulations are established, and as the competition is broadened, expenses with RDI grow again, even though in lower levels than the earlier ones.

Defeuilley and Furtado (2000) analyzing the cases of England and the USA, warned against a decrease in R\&D investments in the sector in the 1990's due to the new regulatory milestones and mainly due to the withdrawal of the State from the R\&D investment. As stated by the authors, if the regulatory milestone does not drive the companies to an internal need to invest in RDI, they will tend to disregard innovation as a strategic element.

Margolis and Kammen (1999) testing the hypothesis of underinvestment in R\&D in the electricity sector in the USA, as well as in the countries members of the International Energy Agency (at the time, with 22 country members), showed that there was a strong reduction in investments in the USA, and a heterogeneous situation in the remaining countries, with most of them presenting a decrease in RDI investments (the most extreme cases were Germany and United Kingdom), and a minority presenting growth (e.g. Japan and Switzerland). These authors showed that within the most important causes for the panorama of decrease in investments in the USA, UK and Germany, there were the directives and the uncertainties related to the new regulatory milestones.

However, the same authors relativized this cause, arguing that the industrial organization and the patterns of competition within the electricity sector in most of the countries naturally reduce the importance of internal $R \& D$ investments.

From a Schumpeterian perspective, this rationale makes a lot of sense.' The absence of essential motivation given by competition, together with a regulatory condition control-ling the gains of the innovator (control of tariffs and produc-tion costs) tend to render innovation a secondary element for the companies. Thus, the business model influences in a decisive manner the rate of investment in R\&D and the search for innovations.

\section{The Brazilian regulatory milestone for RDI in the electricity sector}

As previously noted, since the end of the 1990's Brazil followed the steps of the new regulation movement that took place in the world: sectorial restructuring, introduction of competitive markets, regulation of transmission and distribution networks, creation of independent regulator entity and privatization in some segments (Baer and McDonald, 1998).

Quite probably, already with evidence from the consequences in the European and American processes, the restructuring of the electricity sector in Brazil tried to create a type of safeguard to maintain the R\&D activity: a device, in the national legislation, that obliges companies to invest in research.

The Brazilian regulatory milestone for RDI in the electricity sector arises in the context of sector restructuring. Law

\footnotetext{
'The three most important works of Schumpeter that directly address this theme are: The Theory of Economic Development: An inquiry into profits, capital, credit, interest and the business cycle (1934); Business Cycles:A theoretical, historical and statistical analysis of the Capitalist process (1939) and Capitalism, Socialism and Democracy (1942).
} 
999I, published in 2000, established that the GTD companies must invest $1 \%$ of its $\mathrm{NOI}$ in R\&D projects annually. From the share of the resources to be managed directly by the companies, it would be the responsibility of ANEEL to regulate the investment, assess and approve the execution of research and monitor the results (Campos, et. al., 2007; Cunha, et. al., 2008).

The underlying logic of the model is the following: the companies are obliged to invest part of their income in R\&D.This investment is supposed to be appropriated by the society and not by the company, basically by means of the affordable tariffs policy, resulting in the economic output of the RDI efforts being transferred to the consumers. In other words, the innovator's economic return simply does not exist for the gains due to the RDI efforts will be soon or latter lost during the tariff revision process.

Since the creation of Law 999/ until the present days, two moments with distinct characteristics are identified, which have certainly influenced the R\&D and innovation management models in Brazilian electricity companies. The first moment goes up to the review of the ANEEL's R\&D Program manual in 2008. From an operational point of view, this first moment was guided by the management of what was known among the companies as the "regulatory risk" (the risk of punishment that the companies faced if their investments in research were not accepted by ANEEL).

The second moment starts at the 2008 review and continues up to the present. From this moment on, ANEEL's R\&D Program started to be seen also with an "l" for innovation (RDI efforts and not just R\&D). The main changes were: elimination of pre-approval obligation by ANEEL for investments; creation of three new kinds of projects in what is called the innovation cycle: prototypes, pioneer batch and market insertion; the opportunity of appropriation, even if partial, by the concessionaries of the benefits resulting from the commercialization of new products since these do not affect the internal production costs; the new project inspection focus aimed at research results and not only at the physical-financial control of resources; and, finally, the elimination of the rigid periodicity of annual cycles of investment. The features of this second moment can be found in ANNEL's 2008 R\&D Program manual (ANEEL, 2008).
However, the new regulation did not affect an essential aspect of the innovator motivation: the appropriation of the results of the innovator's efforts within its own core business (generation, transmission and distribution of electricity) was left out. The authorization for partial appropriation of results in RDI was for the commercialization of new products or processes in business models other than GTD.

Finally, it is worth noticing that the regulatory framework, whether in its first or second phase, allows companies to outsource all their obligations of R\&D investment. That means companies can accomplish with their obligations without performing in-house R\&D activities.

In the next sections we present the methodology and the main findings of the study trying to answer the question about the extent in which companies in the electricity sector in Brazil have built their organizational and managerial structures and capabilities to cope with that context.

\section{Methodology}

In order to meet the proposed objectives, an exploratory study was chosen, based on in-depth case studies. According to Yin (2009) the case-study method is suitable for the study of organizational processes, once it preserves the characteristics of real-life events, seeking to answer questions such as "how" and "why" related to the specificities of each situation studied. The choice for a multi-case study is because it allows the collection of more convincing elements, granting greater robustness to the findings (Herriott and Firestone, 1983).

The research focused on some of the main Brazilian concessionaries in terms of their importance to the sector and their relevance regarding RDI investments. A total of seven companies were analyzed.

Table I presents the relative weight of the 7 companies in the set of ANEEL's R\&D Program since 2008 until the beginning of 2013. The seven companies studied answered for $15 \%$ of the projects in ANEEL portfolio and for $27 \%$ of the $R \& D$ investments in the period.

\begin{tabular}{|l|l|l|}
\hline Companies & Companies studied (7) & Total companies (87) \\
\hline Number of projects & 133 & $90 \mathrm{I}$ \\
\hline Total investment (US\$ thousand) & 162,905 & $595,5 \mathrm{I} 2$ \\
\hline Average value per project (US\$ thousand) & $\mathrm{I}, 225$ & $66 \mathrm{I}$ \\
\hline
\end{tabular}

Table I. Relative participation of the sample of companies studied in face of the set of R\&D ANEEL post-2008 regulation Source:The authors (data from ANEEL website - Excel spreadsheet “Projetos_PED-ANEEL_(Res_Norm_316-2008)_Ver20I I.10.03.xls", accessed on October 03, 201I]

ISSN: 07I 8-2724. (http://www.jotmi.org)

Journal of Technology Management \& Innovation (c) Universidad Alberto Hurtado, Facultad de Economía y Negocios. 
The main characteristics of the companies selected in the study are presented in Table 2. In order to keep the secrecy agreed in the research, the companies are named as: Company I, Company 2 and so forth, until Company 7.

The data collection involved bibliographic and documentary research, based on the analysis of the annual reports of the companies, cases presented in events and conferences, as well as other technical publications. The research also involved the application of a semi-structured questionnaire using quantitative and qualitative indicators, depending on the type of information required.

Both bibliographic and documentary research and the application of the questionnaires were organized to obtain information on the four following main themes: i) R\&D and Innovation Profile; ii) R\&D and innovation Management Model; iii) Innovation Strategy; and iv) R\&D and innovation Management Processes.

These themes, as well as the questions and indicators, were selected based on metrics already consolidated by the Oslo Manual (OECD, 2005) adapted to the Brazilian context (IBGE, 2008), and a few recent and important references on the theme of innovation management.
In this context, it is important to highlight the work from Dodgson, et. al., (2008) that addresses the importance of establishing an innovation strategy for the good performance of companies, and works such as Tidd, et. al. (1997), Phaal, et. al. (2006), Adams, et. al. (2006), and Hidalgo and Albors (2008), which address the strategy aspect as well and are dedicated to identify the main tools for R\&D and innovation management. The work of Adams et. al. (2006) address the measuring of innovation management, being of pivotal interest to the research. More recently, the debate on innovation culture has gained more space in literature, presenting specific models and values for the organizational and managerial arrangements aimed at RDI (Gee and Miles, 20I3).

This set of works was complemented by the references from ANEEL's R\&D Program Manual (ANEEL, 2008), in order to bring the discussion closer to the specific context of the Brazilian electricity sector.

The theme R\&D and Innovation Profile was guided towards the collection of information since 2008, according to the typologies defined in ANEEL's R\&D Program Manual, especially on the investment of companies in innovative activities, focusing on the volume and origin of financial resources, amount and type of projects (phases in the innovation chain) [Namely: basic research, applied research, experimental development, prototypes, pioneer batch and market insertion;

\begin{tabular}{|c|c|c|c|c|c|c|c|}
\hline \multirow{2}{*}{ Companies } & \multicolumn{3}{|c|}{ Centralized R\&D management } & \multicolumn{4}{|c|}{ Decentralized R\&D management } \\
\hline & Company I & Company 2 & Company 3 & Company 4 & Company 5 & Company 6 & Company 7 \\
\hline Legal status & $\begin{array}{l}\text { mixed } \\
\text { economy, } \\
\text { state }\end{array}$ & $\begin{array}{c}\text { private, } \\
\text { national } \\
\text { capital }\end{array}$ & $\begin{array}{l}\text { mixed econo- } \\
\text { my, state }\end{array}$ & $\begin{array}{l}\text { mixed econ- } \\
\text { omy, national }\end{array}$ & $\begin{array}{l}\text { mixed econ- } \\
\text { omy, national }\end{array}$ & $\begin{array}{l}\text { private, for- } \\
\text { eign capital }\end{array}$ & $\begin{array}{l}\text { private, na- } \\
\text { tional capital }\end{array}$ \\
\hline $\begin{array}{l}\text { Part of a } \\
\text { holding }\end{array}$ & yes & yes & yes & yes & yes & yes & no \\
\hline Segments & G,T \& D & $G \& D^{*}$ & G,T \& D & G\&T & G\&T & $G \& D^{* *}$ & $\mathrm{D}$ \\
\hline Regions & $\begin{array}{l}\text { in the } 5 \text { re- } \\
\text { gions of the } \\
\text { country }\end{array}$ & $\begin{array}{l}\text { south-east, } \\
\text { south, } \\
\text { north-east } \\
\text { and cen- } \\
\text { tre-west }\end{array}$ & south & $\begin{array}{l}\text { north-east } \\
\text { and north }\end{array}$ & $\begin{array}{l}\text { south-east, } \\
\text { south and } \\
\text { centre-west }\end{array}$ & $\begin{array}{l}\text { south-east, } \\
\text { south and } \\
\text { centre-west }\end{array}$ & south-east \\
\hline Size & large & large & large & large & large & medium & small \\
\hline $\begin{array}{c}\text { N. Employees } \\
(2010)\end{array}$ & 8,859 & 7,924 & 8,560 & 5,638 & 4,906 & 2,378 & 332 \\
\hline $\begin{array}{l}\text { Net Operating } \\
\text { Income }\end{array}$ & US\$ $5.4 \mathrm{bi}$ & US\$ $5.0 \mathrm{bi}$ & US\$ $2.4 \mathrm{bi}^{\text {******}}$ & US\$ $2.0 \mathrm{bi}$ & US\$ $2.7 \mathrm{bi}$ & US\$2.1 bi & US\$ $50.4 \mathrm{mi}$ \\
\hline
\end{tabular}

Table 2. Characteristics of the selected companies

* Only the eight distributor companies were considered for this analysis

** Only one distributor company was considered for this analysis *** 2009 report

Source:The authors (data from annual reports and other open documents available at the websites of each of the companies).

ISSN: 07 I8-2724. (http://www.jotmi.org)

Journal of Technology Management \& Innovation (c) Universidad Alberto Hurtado, Facultad de Economía y Negocios. 
ANEEL, 2008], project execution model (internal or external), relationship with partners and results obtained in projects. The theme R\&D and Innovation Management Model sought to contemplate issues on human resources involved in management activities, on the organizational structure supporting these activities and on the level of centralization/ decentralization of these activities into the company.

The theme Innovation Strategy sought to gather information on the importance of RDI activities to the corporate strategy (based on the expected impacts) and on the formalization of strategies in this theme (existence of a formal investment plan in R\&D and innovation and of an intellectual property policy, as well as the evolution of the protection of intellectual property rights).

Finally, the RDI Management Processes theme was aimed at identifying the level of development in management processes (such as prospection, assessment, project management, intellectual property management, among others), considering its formalization, the use of tools and the dedication in terms of human resources.

The questionnaire was applied on a face-to-face basis (Companies I, 2, 3, 5 and 6) or by telephone (Companies 4 and 7). The applications were held between May, $201 \mathrm{I}$ and January, 2012. The respondents were people directly related to the R\&D and innovation management in the companies: the R\&D and innovation managers and coordinators themselves or, when they were not available, the people dedicated to the RDI management of the company appointed by the coordinator/manager. The next section presents the main results of the case studies.

\section{Results}

As already mentioned, Law 999//2000 demanded that the electricity concessionaries inserted R\&D activities in their routines, creating or adapting internal structures and mobilizing competences to host activities to manage the R\&D investment portfolio. The profiles and models found in the companies studied are analyzed below.

\section{$R \& D$ and innovation profile}

The investment in R\&D by the seven companies accounted for almost US\$ 164 million, invested in I33 R\&D projects. Table 3 shows some figures about the investments amongst the seven companies.

Table 4 presents the percentage participation for the resources invested in R\&D ANEEL projects by phase in the innovation cycle, considering only those projects started since 2008 according to the specifications of the new manual.

These data reveal that despite the creation of new project categories in the new manual, with the objective of bringing the R\&D efforts of the companies closer to innovation itself (whether for the introduction of new products and processes in the market or even in the internal activities of the companies), the phases of applied research and experimental development were the ones receiving the greatest volume of resources in projects for all the companies. The investments in new categories - pioneer batch and insertion in the market - were null for most of the companies.

This situation can probably be explained by the fact that once the companies cannot capture rewards from their innovation efforts, they kept outsourcing projects with universities and research centers where applied research and experimental development are the most common types of projects.

\begin{tabular}{|c|c|c|c|c|c|c|c|}
\hline & \multicolumn{3}{|c|}{ Centralized R\&D management } & \multicolumn{3}{c|}{ Decentralized R\&D management } \\
\hline & Company I & Company 2 & Company 3 & Company 4 & Company 5 & Company 6 & Company 7 \\
\hline $\begin{array}{c}\text { Number of } \\
\text { projects }\end{array}$ & 38 & 16 & 13 & 33 & 19 & 9 & 5 \\
\hline $\begin{array}{c}\text { Total value of } \\
\text { projects (I,000 } \\
\text { US\$) }\end{array}$ & 60,154 & 39,338 & 11,039 & 16,829 & 27,521 & 6,738 & 1,286 \\
\hline $\begin{array}{c}\text { Average value } \\
\text { of projects } \\
(I, 000 \text { US\$) }\end{array}$ & 1,583 & 2,459 & 849 & 510 & 1,449 & 749 & 257 \\
\hline
\end{tabular}

Table 3. Number of R\&D projects and resource volume

Source:The authors, from data extracted from ANEEL website - Excel spreadsheet "Projetos_PED-ANEEL_(Res_Norm_316-2008)_ Ver20II.10.03.xls" [Accessed on October 03, 20II]

ISSN: 07 I8-2724. (http://www.jotmi.org)

Journal of Technology Management \& Innovation (c) Universidad Alberto Hurtado, Facultad de Economía y Negocios. 
Confirming this perspective, all seven companies declared that the projects were performed with external infrastructure and executive team having internal complementation in some very particular cases. From the 7 companies, 4 stated the role of the internal team is only project monitoring. Three of them, Companies 2,5 and 7, said the internal team has some participation in the discussions on the scope and content of projects, but not in the execution.

Most of the companies studied declared that the R\&D projects objectives were headed towards the search for efficiency in internal operational processes at the company, by the demand of its engineering and operational areas, with an essentially incremental character. This point was also observed by Silva Jr., et. al. (2009). Companies I and 2 also mentioned the movements of commercialization of the results generated by means of technology licensing, although still in a very shy manner.Therefore, the generation of new income sources has had a marginal (if any) role when compared to the search for improvements in operational processes and in the reduction of fines and indemnification associated with energy production, transmission and distribution.

\section{R\&D and innovation management model}

Regarding the R\&D and innovation management, all the companies have stated the existence of formal and recognized organizational structure within the company, with full-time dedicated personnel (except for Company 7 , in which the dedication is partial). Table 5 presents a summary of these figures.

From the companies that had centralized R\&D management activities, two of them informed that the current management structure was established in 2009 , after the regulation review in 2008. The redefinition of internal R\&D project management processes was, in this sense, an answer to the signaling by ANEEL on the flexibility and expansion of investments in more advanced phases in the innovation chain.

\begin{tabular}{|c|c|c|c|c|c|c|c|}
\hline $\begin{array}{c}\text { Phases of ANEEL's } \\
\text { innovation cycle }\end{array}$ & \multicolumn{3}{|c|}{ Centralized R\&D management } & \multicolumn{5}{c|}{ Decentralized R\&D management } \\
\hline & Company I & Company 2 & Company 3 & Company 4 & Company 5 & Company 6 & Company 7 \\
\hline Basic research & $0 \%$ & $0 \%$ & $5 \%$ & $8 \%$ & $5 \%$ & $0 \%$ & $30 \%$ \\
\hline Applied research & $45 \%$ & $47 \%$ & $76 \%$ & $63 \%$ & $85 \%$ & $50 \%$ & $70 \%$ \\
\hline $\begin{array}{c}\text { Experimental } \\
\text { development }\end{array}$ & $39 \%$ & $38 \%$ & $16 \%$ & $29 \%$ & $4 \%$ & $50 \%$ & $0 \%$ \\
\hline Prototype & $16 \%$ & $2 \%$ & $3 \%$ & $0 \%$ & $6 \%$ & $0 \%$ & $0 \%$ \\
\hline Pioneer Batch & $0 \%$ & $13 \%$ & $0 \%$ & $0 \%$ & $0 \%$ & $0 \%$ & $0 \%$ \\
\hline $\begin{array}{c}\text { Insertion in the } \\
\text { market }\end{array}$ & $0 \%$ & $0 \%$ & $0 \%$ & $0 \%$ & $0 \%$ & $0 \%$ & $0 \%$ \\
\hline
\end{tabular}

Table 4. Participation in the volume of resources for R\&D projects in the innovation cycle phases (according to ANEEL's R\&D Program manual, 2008).

Source:The authors (data extracted from ANEEL website - Excel spreadsheet "Projetos_PED-ANEEL_(Res_Norm_316-2008)_ Ver20II.I0.03.xls", accessed on October 03, 20II]

\begin{tabular}{|c|c|c|c|c|c|c|c|}
\hline Companies & \multicolumn{3}{|c|}{ Centralized R\&D management } & \multicolumn{3}{c|}{ Decentralized R\&D management } \\
\hline & Company I & Company 2 & Company 3 & Company 4 & Company 5 & Company 6 & Company 7 \\
\hline $\begin{array}{c}\text { A formal unit in the orga- } \\
\text { nization }\end{array}$ & Yes & Yes & Yes & Yes & Yes & Yes & Yes \\
\hline Hierarchical level & $3^{\text {rd. }}$ & $5^{\text {th. }}$ & $3^{\text {rd. }}$ & $3^{\text {rd. }}$ & $4^{\text {th. }}$ & $\begin{array}{c}\text { Not de- } \\
\text { clared }\end{array}$ & $2^{\text {nd. }}$ \\
\hline Dedicated personnel & Yes & Yes & Yes & Yes & Yes & Yes & Partial \\
\hline Number of employees & 6 & 17 & 14 & 6 & 4 & 2 & 4 \\
\hline $\begin{array}{c}\text { Since which year does the } \\
\text { current structure exist }\end{array}$ & 2004 & 2009 & 2009 & 2004 & 2001 & 2006 & 2000 \\
\hline
\end{tabular}

Table 5. RDI Management Structure within the studied companies Source:The authors, from data obtained in the field research.

ISSN: 07 I8-2724. (http://www.jotmi.org)

Journal of Technology Management \& Innovation (c) Universidad Alberto Hurtado, Facultad de Economía y Negocios. 
On the hierarchy of the R\&D and innovation management area, the binding level varied, with the smallest company (Company 7) being the one whose management is at the highest hierarchical level (2nd from a total of 5), reporting directly to the presidency. In the remaining companies the organizational structure is very similar and all of them present 7 hierarchical levels (although with different denominations). Taking this point into consideration, despite having a larger team dedicated to R\&D and innovation management, Company 2 is the one in which this area is at the lowest hierarchical level.

A study performed with the energy distribution companies by ABRADEE (2009) also pointed out that in $27 \%$ of the companies R\&D management was situated in the 2 nd hierarchical level, and in $73 \%$ of the companies this area was in the 3rd or 4th hierarchical level, coherent with the data found in this study.

All companies studied comply with ANEEL's obligation of having internal employees acting as project managers (PM). However, all of them declared that the PM has only partial dedication to this task, which represents an extra effort to their routine activities. When questioned about the creation of some award or payment incentive mechanism to these PMs, the companies recognize that the main return to the PM is the possibility of taking a post-graduation course on the project subject, as well as participating in events and seminars related to it.

\section{Innovation strategy}

Most companies have declared that their R\&D and innovation activities were seen, until the publication of the new manual in 2008 , as an answer to the regulatory requirements and legal obligations of the sector. The research performed by ABRADEE in 2009 already emphasized this same point. Little importance was given to the potential of these activities in promoting an increase in the economic-financial performance of the companies, diversifying their services or products with the generation of new businesses and the conquering of new markets.

As already discussed, considering a market structure with little competition, in a strongly regulated sector, these results are indeed expected. There was no clear concern in guiding the projects towards the needs of the company or to the global technological challenges in this area of knowledge, much less in creating opportunities for commercialization, generation and diversification of new businesses. This same interpretation can be seen in the research performed by ABRADEE (ABRADEE, 2009) and Ferro (2009).

Another relevant indicator for the analysis of the strategic importance granted to RDI is that of the existence of internal policies for intellectual property. The data presented in Table 6 show, in agreement with previous results, that intellectual property (IP) is not a well-established process nor is one of great importance in the companies, since four of them have stated not having a formal IP policy, and two stated that there is a policy, albeit informal. The companies declared the number of protections for each of the types is presented in Table 6.

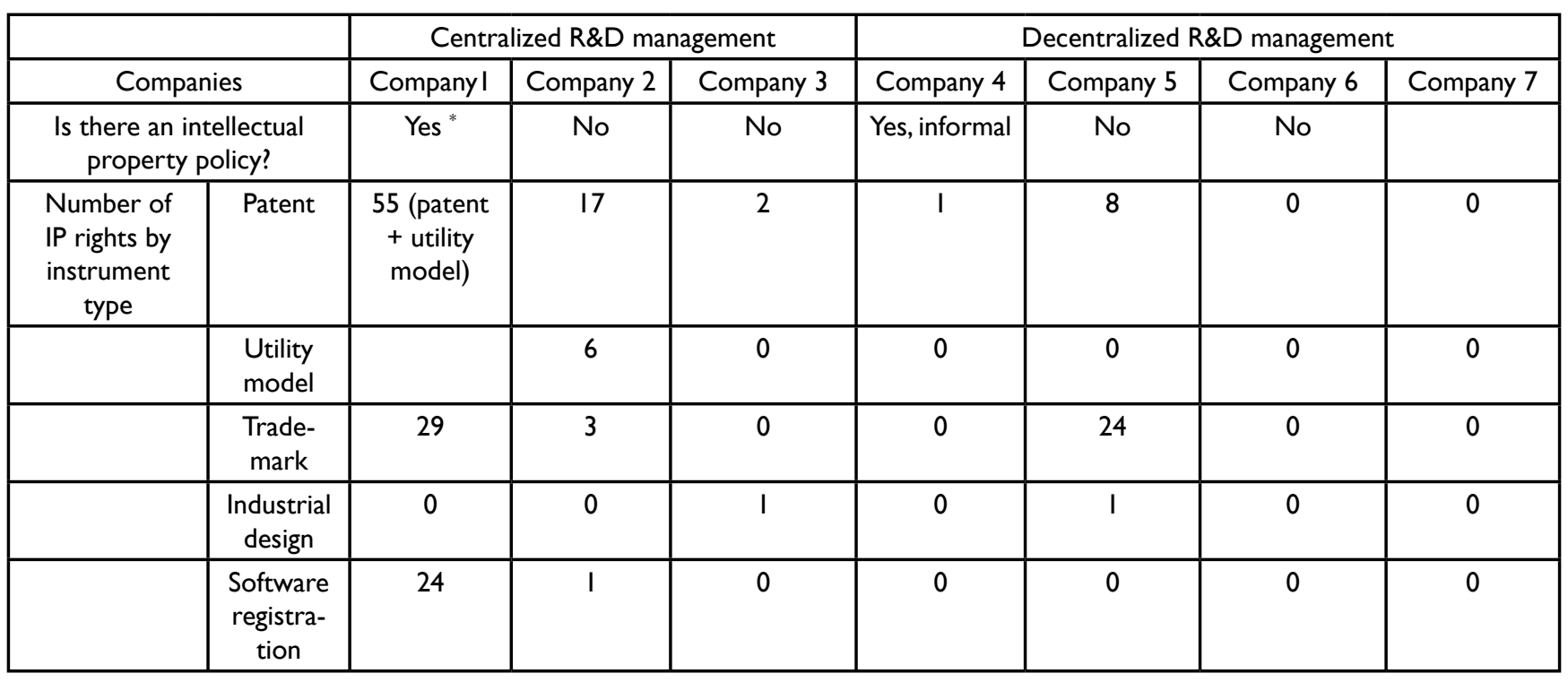

Table 6. Intellectual property rights and strategies * The company has a policy that has not been totally incorporated. Source:The authors (data obtained during the questionnaire application)

ISSN: 07 I8-2724. (http://www.jotmi.org)

Journal of Technology Management \& Innovation (c) Universidad Alberto Hurtado, Facultad de Economía y Negocios. 
Company I, despite not having a formally established policy, presents a number of requests for protection that is much higher when compared to the remaining companies of the sample. During some years, even before the existence of the legal obligation of investing in R\&D, the company had already had a strong participation in the development of engineering solutions, with a well-qualified engineering technical team stimulated by the company to patent their developments.

During the questionnaire application, Company I informed that it already had products being commercialized, by means of technology licensing, with the forecast of paying $10 \%$ of the revenue originated from royalties. Company 2 has also stood out in this theme, reporting 5 cases of licensing: one invention patent, two utility model patents and one software registration (and there was also the same technology licensed to two different companies). However, such processes were very recent at the time of the research and therefore they had not yet generated important payment of royalties.

ANEEL has reported in the 2007 edition of its R\&D Magazine (ANEEL, 20I0) that by the end of 2005 from the 1424 projects performed so far, 129 resulted in the request for patents. Among the main causes reported for the failure in obtaining patents claimed in this survey, the companies justified that: a) in general the product developed in the project was not patentable; $b$ ) the result of the project had not been satisfactory; c) the company had no interest in the patent registration process, nor in the financial benefits originated from the commercial exploitation of the IP.

\section{R\&D and innovation management processes}

During the questionnaire application, the companies were also asked about the level of development of their R\&D and innovation management processes, considering their formalization, the use of tools and the dedication in terms of human resources.

It can be stated that there are similarities capable of defining an R\&D management pattern in the companies analyzed, whose focus is on complying with the obligations defined by ANEEL, and which is primarily directed towards rigid controls on projects and resources invested.

The research indicates there is little effort towards the formalization of processes for "technological and market pros-

\footnotetext{
${ }^{2}$ It is important to highlight that, since it is a process for the devel-opment of regulated projects, many of the criteria used for the selection and prioritization of new projects follow the assessment indicators defined by ANEEL in its new R\&D manual from 2008, such as: i) Originality; ii) Applicability; iii) Relevance; and iv) Rea-sonableness of costs.
}

pecting" guided towards prioritization and decision making process. Only Companies 2 and 3 presented some level of formality in these processes, even though not presenting the usage of specific tools or methodologies, and not having an exclusively dedicated team.

On the other hand, more significant efforts can be seen regarding the "selection and prioritization" of themes and projects that are to be part of the R\&D portfolio of these companies. Except for Company 7, all the remaining companies used some methodology or tool for prioritization, with greater emphasis for Companies 3 and 4, which had a well-established level of formalization by means of routinized processes. ${ }^{2}$

The process with the highest formalization levels in the companies is "project management". The regulation itself guides the company's efforts towards this type of activity. Until the publication of its manual in 2008, ANEEL demanded the use of a project form. Even though the change in the regulation in 2008 extinguished the requirement of using this form, three out of the seven companies still use the same model. One of them acquired a market-ready tool for project management, another sought to customize the already existing tools, and the remaining ones used simplified Word or Excel forms.

None of the companies in the studied sample performed a systematic "assessment of results and impacts" on its project portfolio. A few perform this assessment in a sporadic manner, hiring external assessment. This subject is still quite restricted and it is not among the main management concerns of the studied companies.

The "management of financial resources" for research and innovation is associated both with the management of mandatory investment defined by Law 999//2000 and with the possibility of using other funds for financing RDI, or even using fiscal innovation incentives. In this regard, if on one side all companies state the existence of a systematic process for financially monitoring the projects, on the other, only Company I declared having sought new sources for financing RDI, having captured resources at the Brazilian Innovation Agency. This point is very important since it reveals that the legal obligation of investing in RDI has not leveraged the interest of GTD companies in seeking new and extremely interesting financing sources currently existing in Brazil.

The process of "managing research networks" might be one of the themes that have advanced more. With the external hiring of researchers from universities, research centers and technology companies, the concessionaries could map and know competencies, creating relationships they had not before. 
The processes of "commercialization of technological products" and "planning for internal absorption/incorporation of technological results" are related with the appropriation or use of the results generated in the projects. As already discussed, most companies consider the application for internal benefit and use as the main focus of results for R\&D projects, with little interest in the commercialization of these results. Therefore, there are only few companies that have structure and planning for this activity (with emphasis on Companies 2 and 5).

\section{Discussion}

The information obtained showed that the innovation policies, specifically Law $9991 / 2000$, contributed in a very timid manner to the evolution of innovation management capabilities within the companies. It could be observed, in practice, that R\&D management processes have been going through a long learning period, modulated by rules $d$ efined by ANEEL and the relative importance the subject has in business strategies.

Seen more as an obligation rather than an opportunity, the advances related to the R\&D and innovation management at the companies are coherent with the historical, regulatory and market structure context of the sector.After more than 12 years since the policy was implemented, and even considering the period of more than 4 years after the 2008 regulation, the companies have built minimalist management structures, in the sense of minimum allocation of resources (human, financial and material) for the internal organization of RDI execution and management activities.

This result is coherent with what was found by other authors analyzing similar cases in other countries and in Brazil. Particularly, the works of Margolis and Kammen (1999) and of Jamasb and Pollitt $(2008 ; 201 \mathrm{I})$ show that the sectorial reorganization process with privatization and regulation using models similar to the Brazilian one has resulted in the lowering of interest by the companies in investing in RDI. The studies of ABRADEE (2009), Ferro (2009) and Tenório (2009) also addressed similar conclusions analyzing the Brazilian case.

The result observed in this research was the establishment of management models based much more on the control of means (project resources and execution) than on final results (opportunities arising from the development of new solutions).

As a heroic hypothesis, it is possible to think that the absence of more developed processes for prospecting technologies and market, managing intellectual property, commercializing technology, among other processes prior to 2008 could have hampered the development of these competences and managerial structures. However, the most probable hypothesis is that the 2008 regulation, even though bringing more flexible elements for the companies, has not substantially changed the most important issues in order to unleash the innovation culture and to develop RDI managerial practices, keeping closer to the original regulation than to a new policy. On the other hand, it must be mentioned that the companies managed to create important research networks in the country, connecting themselves to research centers, universities and technology-based companies to execute the projects. As pointed out by Pompermayer, et. al. (20I I), this was one of the main results from the external hiring effort of R\&D ANEEL, despite noticing that in the first period, there had been a strong hiring concentration in approximately 10 research organizations.

Actually the effects of R\&D ANEEL were much larger outside the companies than within them, in the sense that the resources from the legal obligation were performed in other institutions (Pompermayer, et. al., 20I I).

Thus, despite the existence of specific teams of dedicated professionals, very few processes were systematized and became part of the companies' strategies. Although there are differences among them, a clear movement for incorporating RDI in their strategic guidelines and in their organizational and managerial models could not be distinguished in any of them.

The companies studied did not evolve from a model founded on the control of project portfolio to avoid the regulatory risk to a proper RDI management model, which would include the forming of specific competences and the structuring of dedicated and specialized areas, as well as being better positioned in the organizational structure.

More recently, it is possible to note initiatives to professionalize the RDI management within the companies. As seen, there are signs of the valuing of RDI importance within the institutional hierarchy. However, there is no way to know if this will become a new stage in R\&D in the electricity sector. Market conditions, new technologies and fundamentally the evolution of the regulatory milestone will reinforce or weaken these signs.A priori, one cannot discard any possibility: it is both possible to think on a more or less accelerated strengthening of the RDI importance in the sector and in an opposite situation in which RDI is simply eliminated from the routines in GTD companies.

Both scenarios are possible. More drastic changes in the regulatory milestone can lead to any of them. For instance, if the current market conditions remain as they are, with strong control over tariffs and without the perspec- 
tive of competition, the removal of the mandatory investment in RDI would simply eliminate the R\&D efforts in most of the companies (it is not rare to find in the sector the conviction that the current RDI structures only exist due to the legal obligation).

On the other hand, a change in the stimuli to the appropriation of the results from the RDI effort, as well as the new technology perspectives founded on the distributed generation (smart grid) and on the focus on consumer services can transform the market structures, leading to a more competitive model with growing demands for innovation.

\section{Conclusions}

This paper aimed to identify and analyze the evolution of structures and competences of research, development and innovation management in concessionary companies in the national electricity sector, from a sample of seven companies representing over $27 \%$ of the resources applied in research projects by the companies within the ANEEL's R\&D Program.

From a multi-case and literature analysis on the theme, it is stated that the companies have indeed structured their management models, but did so following a minimalist structure, using the minimum necessary in terms of resources with the main objective of managing the regulatory risk of R\&D investment, despite having heterogeneities among them. Even when considering these differences, the fact is that none of them had systematized and professionalized organizational and managerial models for RDI management.

Thus, answering the initial question of the research we shall say that companies did build their structures but under a minimalist perspective focused on the control of regulatory risk: perform the annual obligation of contracting RDI projects, complying with the legal device and ANEEL rules to not incur in punishment. There were efforts from companies, especially in selecting projects and managing portfolios, but these efforts are still far from characterizing the emergence of organizational structures for RDI management, especially if one takes in consideration the volume of financial resources annually spent for RDI, above of tens of million dollars for many of the companies. ${ }^{3}$

\footnotetext{
${ }^{3}$ The current scenario is not very encouraging for the theme. In 20I3, the government passed Law 12783 as a new policy for reducing electricity tariffs that will cause a reduction in the profit margin of the companies and thus, one more disincentive to undertake RDI efforts. Moreover, the same Law extended for up to 30 years concessions that would expire in 2017.
}

From the point of view of the innovation policy in the sector, it is essential to monitor these aspects, so that they do not perpetuate a model in which the main driver is the obligation, without any or very low incentives. Innovation will not happen if the companies do not have concrete stimuli based on rewards and not only in punishment.

There is no serious theoretical model that sustains the virtuous expectation in this environment sustained only by obligation, as well as there is no evidence capable of showing the effectiveness of the policy adopted. The policies can indeed be voluntaristic, but cannot ignore the fundamentals of the capitalist dynamic under the risk of ineffectiveness.

\section{References}

ABRADEE - ASSOCIAÇÃO BRASILEIRA DE DISTRIBUIDORAS DE ENERGIA ELÉTRICA. (2009). ABRADEE Survey: Benchmarking da Gestão do P\&D nas Concessionárias de Distribuição de Energia Elétrica: Organização e Infra-Estrutura.ABRADEE, Brasília-DF.

ADAMS, R., Bessant, J., Phelps, R. (2006). Innovation management measurement: A review. International Journal of Management Reviews, 8(I), 2I-47.

ANEEL - Agência Nacional de Energia Elétrica (2008). Manual do programa de Pesquisa e Desenvolvimento tecnológico do setor de energia elétrica 2008. Brasília, DF. http://www. aneel.gov.br/. [Accessed December 02, 20I I].

ANEEL -Agência Nacional de energia Elétrica (2010). http:// www.aneel.gov.br/. [Accessed May 26, 2010].

BAER,W., McDonald, C. (1998).A return to the past? Brazil's privatization of public utilities: The case of the electric power sector. The Quarterly Review of Economics and Finance, 38(3), 503-523.

CAMPOS, I.A. (2007). Potencialidades e Energias Renováveis no Brasil: Perspectiva Eólica. Io Seminário do Centro-Oeste de Energias Renováveis. Goiânia.

CUNHA J. C., Silva E., Dias C., Girardi S. (2008). Sistema Setorial de Inovação de Energia Elétrica no Brasil: Estrutura e Trajetórias. XXV Simpósio de Gestão da Inovação Tecnológica. Brasília-DF.

DEFEUILLEY, C., Furtado,A.T. (2000). Impacts de l'ouverture à la concurrence sur la R\&D dans le secteur électrique. Annals of Public and Cooperative Economics, 7I(I), 5-28.

DODGSON, M., Gann, D., Salter,A. (2008).The Management of Technological Innovation: Strategy and Practice. Oxford University Press, New York. 
FERRO, A. F. P. (2009). Modelos de seleção e priorização de atividades de P\&D.Working Paper. Departamento de Política Científica e Tecnológica, Universidade Estadual de Campinas.

FURTADO, A. (20II). O sistema setorial de inovação do setor elétrico brasileiro e o CTEnerg. IPEA, Campinas.

GEE, S., Miles, I. (20I3). Cultures and Innovation. In: Cox, D., Rigby, J. (Eds.). Innovation Policy Challenges of the 2 Istdu Century. Routledge, New York. pp. 244-267.

HELM, D., Jenkinson T. (1998). Competition in Regulated Industries. Oxford University Press, New York.

HERRIOTT, R. E., Firestone,W.A. (1983). Multiuse qualitative policy research: optimizing description and generalizability. Educational Researcher, 12 (2), I4- I9.

HIDALGO A., Albors J. (2008). Innovation management techniques and tools: a review from theory and practice. R\&D Management, 38(2), I I3-I 27.

IBGE - Instituto Brasileiro de Geografia e Estatística (2008). Pesquisa de Inovação Tecnológica - PINTEC 2008. IBGE, Rio de Janeiro.

JAMASB, T. (2006). Between the state and market: Electricity sector reform in developing countries. Utilities Policy, I4(I), I4-30.

JAMASB, T., Pollitt, M. (2008). Liberalisation and R\&D in network industries: The case of the electricity industry. Research Policy, 37(6-7), 995-1008.

JAMASB, T., Pollitt, M. (20I I). Electricity sector liberalisation and innovation: An analysis of the UK's patenting activities. Research Policy, 40(2), 309-324.

JANNUZZI, G. M. (2000). Energy efficiency and restructuring of the Brazilian power sector. Energy for Sustainable Development, 4(2), 17-22.

JANNUZZI, G. M. (2005). Power sector reforms in Brazil and its impacts on energy efficiency and research and development activities. Energy Policy, 33(I3), I753-1762.

MARGOLIS, R. M., Kammen D. M. (1999). Underinvestment: The Energy Technology and R\&D Policy Challenge. Science, 285 (5428), 690-692.

OECD. (2005). Oslo Manual: guidelines for collecting and interpreting innovation data, 3rd ed. OECD Publishing, Paris.
PAVITT, K. (1984). Sectoral patterns of technical change: towards a taxonomy and a theory, Research Policy, $13(6), 343-373$.

PHAAL, R., Farrukh, C. J. P., Probert, D. R. (2006) Technology management tools: concept, development and application. Technovation, 26(3), 336-344.

POMPERMAYER, F. M., De Negri, F., Paulo, J. M. P., Cavalcante, L. R. (20II). Rede de pesquisa formada pelo programa de P\&D regulado pela ANEEL: abrangência e características. In: Pompermayer, F. M., De Negri, F., Cavalcante, L. R. (Org). Inovação tecnológica no setor elétrico brasileiro: uma avaliação do programa de P\&D regulado pela ANEEL. Ed. IPEA, Brasília-DF.

SCHIMITT, S., Kucsera, D. (2013). The Impact of the Regulatory Reform Process on R\&D Investment of European Electricity Utilities. Beiträge zur Jahrestagung des Vereins für Socialpolitik 2013: Wettbewerbspolitik und Regulierung in einer globalen Wirtschaftsordnung - Session: Regulated Industries, No.A I4-V3.

SCHUMPETER, J.A. (1934). The Theory of Economic Development:An Inquiry into Profits, Capital, Credit, Interest, and the Business Cycle, Harvard University Press, Cambridge.

SCHUMPETER, J. A. (1939). Business cycles: a theoretical, historical and statistical analysis of the capitalist process. Mcgraw-Hill, New York.

SCHUMPETER, J. A. (1942). Capitalism, Socialism and Democracy. George Allen \& Unwin, London.

SILVA Jr., R. G., Procopiuck, M., Quandt, C. O. (2009). A Pesquisa e Desenvolvimento na Estratégia Competitiva das Concessionárias do Setor Elétrico Brasileiro. XII Simpósio de Administração da Produção, Logística e Operações Internacionais, São Paulo.

SOARES, V. R. (1997). Mudanças Institucional e Organizacional no Setor Elétrico Brasileiro Frente às Novas Tendências da Dinâmica Tecnológica. PhD Thesis. Faculdade de Engenharia da Universidade Estadual de Campinas.

TENÓRIO, J. B. Jr. (2009). Indicadores e métricas: ferramentas para avaliação de resultados de P\&D visando a inovação no setor elétrico. Master Degree Dissertation. Pontifícia Universidade Católica do Rio de Janeiro.

TIDD, J., Bessant, J., Pavitt, K. (1997). Managing innovation: integrating technological, market and organizational change. Ist Ed., John Wiley, New York. 
YIN, R. K. (2009). Case Study Research: design and methods. 4rd Ed. Sage Publications, Thousand Oaks. 